\title{
Agro Based Linkages between Soil Erosion and Income Generating Activities of Rural Women in Anambra State, Nigeria
}

\author{
Uzokwe, U.N. \\ Department of Agricultural Economics and Extension Delta State University Asaba Campus
}

\begin{abstract}
This study considered the agro-based linkages between soil erosion and income generating activitives of rural women in Anambra State. The specific objectives were to: determine the agro-based income generating activities of rural women in Anambra State; ascertain if there were differences in the income generating activities in sheet and gully erosion areas, establish if the IGAs are affected by erosion and determine the extent to which they are affected in sheet and gulley erosion areas. The study was carried out in Anambra State. Interview Schedule and Focus Group Discussion(FGD) were used to collect data. The state was stratified into six strata according to erosion types. Stratified and purposive sampling methods were used to determine a sample of 600 respondents for the Interview Schedule while one FGD was carried out in each of the six strata. The result showed that the average age of respondents was 34years, $75.8 \%$ were married with an average of 4 children, $20 \%$ had no formal education and $76 \%$ of them were christians. Most of the women are involved in crop farming (87.85\%), palmoil processing (61.75\%), cassava processing (87.95), keeping of local fowl (75.4\%), sale of vegetables (62.9\%), and goat rearing (54.85\%). The most affected IGAs in sheet and gully erosion areas are goat rearing (62.3\% and 33.7\%),( 50.7\% and 50.3\%), crop farming (44.6\% and 59.9\%). The study showed that the agrobased IGAs of the women are affected by erosion and since land is their main factor of production, it is likely to affect their food security.
\end{abstract}

Key words: Agrobased, linkages, erosion and income generating activities

\section{Introduction}

The environment and its significance to human life has increasingly become the focus of national and international attention. There is a greater awareness of the destructive effect of centuries of uncontrolled exploitation of the environment without conscious effort at replacing the used resources. Environmental degradation has become a cliché that frequently appears as top level news.

In the entire world, agents of degradation e.g. wind, water and oil spills appear to be gathering more force in their ravaging effect. Climatic patterns have failed and there are swings from dryness and scorching heat summers to excessive rainfall and extreme cold winters. Excessive rain does not only result in flood and erosion which has claimed millions of lives but also washes away the top soil rendering the agricultural land unproductive. In addition it results in complete loss of farmland and property.

According to Eboh (1995) soil erosion by water is particularly acute in areas of Southern Nigeria. Ofomata (1991) postulates that soil erosion is the most striking feature on land surface of Southern Nigeria. The Nigeria Environmental Study Action Team (NEST) (1991) observed that gully erosion is the most observable, best documented and most frightful type of erosion in the country. It occurs in areas of soft rocks like Anambra and Imo States where they develop very rapidly. Igbozurike (1981) confirmed that rill erosion or gully erosion is particularly high in parts of Nigeria where the rainfall exceeds $1,500 \mathrm{~mm}$.

Anambra State is a high erosion prone area with devastating gullies in communities including Ichi, Achalla, Nnewi and Agulu. According to NEST (1991) the Agulu-Nnaka gully erosion complex is one of the five largest in the world. Igbozurike (1981) estimated the extent of soil erosion problem in Southern Nigeria as 29\% of the total land area, and NEST (1991) postulates that over half of the 441 autonomous communities inhabiting the area are ravaged by gully erosion.

Soil erosion does not only affect soil fertility but it also results to loss of arable land causing decline in crop production. NEST (1991) reported truncation of farm roads making it impossible to access their farms. The enormity of the erosion problem in the South Eastern states and the environmental hazards associated with it, have imposed a big challenge to stakeholders and researchers hence the need for this study.

The general objective of this study was to examine possible linkages between erosion and income generating activities of women in affected areas, and the extent to which erosion affects the income generation of rural women in Anambra State. The specific objectives were to:

1. determine the agro-based income generating activities of rural women in Anambra State

2. ascertain if there are differences in the income generating activities in sheet and gully erosion areas.

3. establish if the IGAs are affected by erosion and

4. determine the extent to which they are affected in sheet and gulley erosion areas. 


\section{CONCEPTUAL FRAME WORK}

The Conceptual framework of the study is as shown in Fig 1.

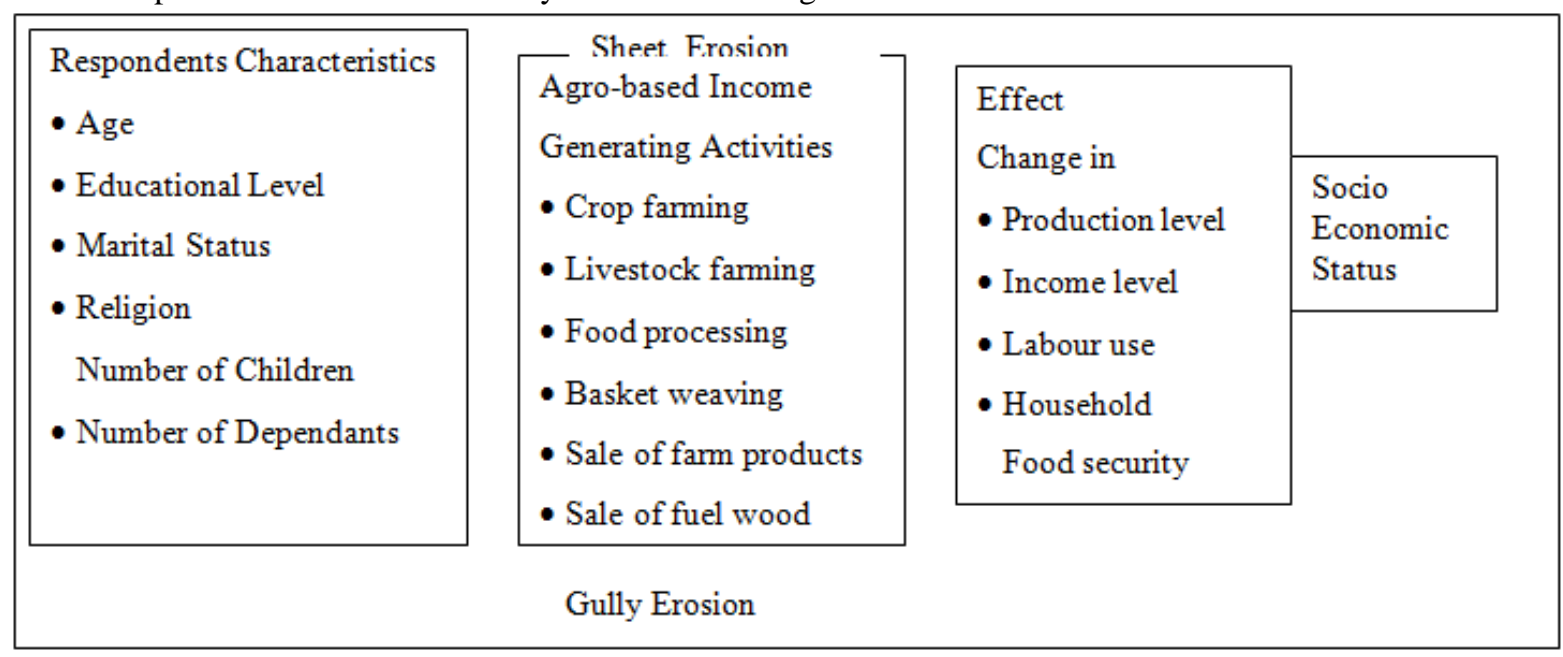

Fig. 1 Conceptual framework showing linkages between soil erosion and income generating activities.

The conceptual Framework nerating activities are Fig. 1 presents the conceptual model of this study. Environmental degradation and respondents characteristics are the independent variables while income generating activities are the dependent variable. The effect represents the outcome of the interaction between the variables.

\section{Erosion and Income Generating Activities}

The flow chart represents an environment degraded by both sheet and gully erosion types. It is in this degraded environment that the women live and carry out their income generating activities (IGAs). Sheet and gully erosion is likely to affect the IGAs of rural women since most of their IGAs are agro-based and consequently sourced from land. These include crop farming, livestock farming, food processing, basket and cloth weaving, collection of fuel wood and sale of farm produce. Erosion is the degrading force ravaging Anambra State, and according to Udo (1990) and Oformata (1991), erosion results in change of production level, income level, labour use, household food security and all these affect the socio-economic status (SES) of women.The production level marks a likely decrease in the quality of crops produced by them because of physical and chemical damage done to the soil. More effort has to be put in by women to achieve maximum productivity especially in their farming activities. World Bank (1990) puts the country wide estimate of annual soil loss through erosion at 25 million tons, with maize yield declining from 6.5 tons to as little as 1 ton per hectare. When production level drops the income will also drop and the family food security will be at bay.

\section{Respondents' Characteristics and Income Generation}

The income generating activities of rural women in Anambra State can enhance or adversely affect their demographic characteristics. These activities include: farming, food processing, collection of fuel wood, sale of farm produce and fuel wood, and basket weaving. The demographic characteristics affect the agro-based income generating activities of rural women in the following ways:

Age

The older a women gets, the less energetic she becomes and the less income she is likely to generate. This affects the agro-based income generating activities which need lots of energy. The young women in their active child bearing age are likely to generate less income than middle aged women. Child bearing and rearing take their time and energy, so they have less time and energy for engaging in income generating activities.

\section{Marital Status}

A married woman in most cases has more responsibility than an unmarried woman. She has a commitment to ensure her family food security. To ensure her family is well catered for, the rural married (rather than unmarried) woman is likely to engage in multiple IGAs to enable her provide adequately for her household 


\section{Educational Level}

A literate woman is likely to exercise multiple options in her ability to generate income. She might be in more sophisticated non agro-based trade like dress making. She can even get employed in a cottage industry or be a school teacher or community health worker or in any similar employment. She can afford to use hired labour in her farm, belong to cooperatives from which she can have access to farm inputs which will improve her income. She is likely to be involved even more in food processing than production.

\section{Number of Children}

The more children a woman has, the more mouths she has to feed and the more she must work hard to enable her accomplish this task. Multiple deliveries affect a woman's physical fitness and therefore her capability to generate income. Eboh, (1994) explained that families that have more children will have more hands to work on the farm. This is possible only if the children have grown to the age of being farm helps, but when they are still very young at least below 10 years of age they are solely dependant. This means that the women have to work to generate income to fend for them.

\section{Age of Children}

A woman who has grown up children has a lot of help in generating income. It is also easy for her to diversify if she wants. Even if she is entirely into agro-based IGAs, she is likely to do better with the help of her children. She is therefore likely to be better off than the woman with little children.

\section{Dependants}

In Anambra State, like in other parts of Nigeria especially in the rural setting, the extended family system abound. These dependants increase the budget of the families, but at the same time contribute to the income sometimes. They can even contribute more than is spent on them. With their help in the IGAs of a woman, she is able to carry out these activities on a larger scale than if she did not have them. This on the long run can help enhance the household food security.

\section{Religion}

In Anambra State which is the area of study, the people are predominately Christian. Unlike the Moslem women they are not largely restricted to the type of agro-based income generating activities they engage in. The only cultural stereotype is seen in the cultivation of crops like yam which is regarded as male crop.

In conclusion the demographic characteristics affected the income generating activities of rural women. The status of their demographic characteristics and the extent to which their farm lands, road and other facilities on their farm have been affected by erosion is a determinant of the type of IGAs they carry out and the success for them too. These determine the final effect on their family income and consequently their socio-economic status.

\section{Methodology}

This study was carried out in Anambra State, Nigeria. The data for this study were collected using two data collection tools, viz. Focus Group Discussion (FGD) and interview schedule. Stratified sampling method was used to select respondents. For the purpose of this study the state was stratified into 6 strata using the Ofomata (1995) stratification of slight sheet, moderate sheet and severe sheet; mild gully, severe gully and devastating gully.

\section{Focus Group Discussion (FGD)}

This was carried out simultaneously with the pre-test of the interview schedule (IS). It helped to fill in information gaps left by the interviews as well as get in-depth information which is useful in reporting the information obtained from the interviews for better understanding. Six FGDs were carried out, one in each stratum. In each of the six villages selected 7 to 11 women were chosen from women famers or cooperative groups in the village. In each case the president and the secretary were always included. Table 1 shows the villages, the number of women used and the names of the women groups from which the FGD participants were selected.

Table 1: Composition of the Focus groups

\begin{tabular}{|l|l|l|l|}
\hline Erosion Strata & Villages & No. women used & Name of women groups \\
\hline Slight sheet & Odekpe & 8 & Anibueze women group \\
\hline Moderate sheet & Ojoto-Uno & 9 & Ofuobi Isogwugwu fadama women group \\
\hline Severe sheet & Nteje & 7 & Okanna Na Okpoko women group \\
\hline Mild gully & Ebenebe & 10 & Obuno women group \\
\hline Severe gully & Osumenyi & 11 & Osumenyi women group \\
\hline Devastating gully & Nnewichi & 10 & Ogbo Women Multipurpose society \\
\hline
\end{tabular}




\section{Administration of interview Schedule}

About (10\%) percent of the villages in each stratum were chosen using simple random sampling. This resulted in 17 villages. Table 2 shows the villages that were selected in each erosion stratum. To determine the number of women to be included in the sample, proportional sampling method was used.

Table 2: Distribution of villages in each stratum and their women population

\begin{tabular}{|l|l|l|}
\hline Erosion Strata & No. of villages & Women population \\
\hline Slight sheet & 26 & 175,180 \\
\hline Moderate sheet & 55 & 205,222 \\
\hline Severe sheet & 21 & 114,506 \\
\hline Mild gully & 19 & 69,357 \\
\hline Severe gully & 13 & 79,857 \\
\hline Devastating gully & 07 & 38,311 \\
\hline
\end{tabular}

One hundred women were predetermined to be sampled from each stratum. A total of 600 women were used for the administration of the interview schedule. Table 3 also shows the villages used in each stratum, women population and the sample size.

Table 3: Villages in each stratum, women population and sample size

\begin{tabular}{|l|l|l|l|}
\hline Strata of erosion type & Villages & Women Population & Sample size \\
\hline Slight sheet & Umuleri & 5,037 & 39 \\
& Ohita & 780 & 05 \\
& Ogu-Ikpele & 7,437 & 56 \\
\hline Moderate sheet & Mbosi & 3,820 & 12 \\
& Ezinifite & 7,937 & 25 \\
& Amesi & 5,481 & 17 \\
& Akpu & 1,456 & 05 \\
& Ndikelionwu & 2,493 & 10 \\
& Oko & 9,682 & 31 \\
\hline Severe sheet & Adazi-Ani & 4,759 & 47 \\
& Umunya & 5,325 & 31 \\
\hline Mild gully & Amansea & 1584 & 27 \\
\hline Severe gully & Nsugbe & 4,302 & 73 \\
\hline Devastating gully & Abacha & 2,160 & 41 \\
& Ideani & 3,116 & 59 \\
\hline
\end{tabular}

\section{Measurement and Standardization of Variables}

Majority of the variables measured in this study are estimates which depended on the memory of the women. Some of the variables like farm size, and quantity of food crops required standardization. The standardization and operationalization techniques were used to measure farm size and income generating activities parameters. Farmland sizes were measured in heaps per hectares using approximately 6,500 heaps per hectare. On the other hand the income generating activities were determined by asking the respondents to indicate the ones they were involved in. The list of activities included crop planting, palm oil processing, oil bean processing, cassava processing, breadfruit processing, keeping of local fowl, keeping of exotic chicken, goat rearing, pig rearing, fishing, sale of leafy vegetables, grains, fuel wood and basket weaving. The respondents were asked to answer "yes" or "no" to indicate their involvement in each of the activities; "yes" was scored 2 and "no" 1.

\section{Results And Discussion}

Table 4: Personal Characteristics of Respondents

\begin{tabular}{|l|l|}
\hline Characteristic & Percentages \\
\hline Age in Years & \\
$>\mathbf{2 0}$ & $\mathbf{2 6 . 2}$ \\
$\mathbf{2 1}-\mathbf{4 0}$ & $\mathbf{1 8 . 3}$ \\
$\mathbf{4 1}-\mathbf{6 0}$ & $\mathbf{4 7 . 8}$ \\
$\mathbf{6 1}-\mathbf{8 0}$ & $\mathbf{7 . 3}$ \\
$\mathbf{8 1}-\mathbf{1 0 0}$ & $\mathbf{2 . 4}$ \\
\hline Marital Status & \\
Married & $\mathbf{9 8}$ \\
Single & $\mathbf{2}$ \\
\hline Family Size & \\
$1-5$ & 56.2 \\
$6-10$ & 28.9 \\
$11-15$ & 14.0 \\
\hline
\end{tabular}




\begin{tabular}{|l|l|}
\hline $16-20$ & 0.9 \\
\hline Religion & \\
Christian & 76 \\
Traditional worshippers & 17 \\
Muslims & 7 \\
\hline Education level & \\
Non formal & 20.23 \\
Primary school not completed & 17.22 \\
Primary school completed & 20.74 \\
Secondary school not completed & 15.45 \\
Secondary school completed & 14.09 \\
Tertiary & 12.32 \\
\hline Main Occupation & \\
Crop farming & 45.70 \\
Livestock farming & 4.50 \\
Trading & 29.60 \\
Food processing & 12.40 \\
Basket weaving & 2.80 \\
Dressmaking & 2.00 \\
Hired labour & 0.90 \\
Food vending & 1.90 \\
\hline Years in given occupation & \\
Below 1 year & 8.39 \\
1 - 5 years & 10.11 \\
6-10 years & 18.90 \\
$11-15$ years & 19.84 \\
16-20 years & 27.09 \\
Above 20 years & 15.64 \\
Total & $\mathbf{1 0 0 . 0 0}$ \\
\hline Number of children of respondents & \\
1 - 5 & 56.2 \\
6-10 & 28.9 \\
11 - 15 & 14.0 \\
$16-20$ & 0.9 \\
\hline & \\
\hline
\end{tabular}

\section{Personal Characteristics of Respondents}

Table 4 shows that most of the respondents fall between the age range of 41 to 60 years $(47.8 \%)$. This agrees with the studies of Oladele (1999) who discovered that most of his respondents (59\%) in his study in South Western Nigeria fall within this age bracket. It also agrees with Ladele (1990) who recorded that most of his respondents $(64.8 \%)$ fall between the same age range in his study of farmers in Kwara and Oyo States of Nigeria. Studies by Onorah (1992) on rural Women in Anambra Local Government Area and Akinlua (1997) in Oyo L.G.A. reported that most of their respondents fall between the ages of $30-50$ years $(81 \%$ and $72 \%)$ respectively. In all these studies there is an indication of a concentration of respondents between the ages of 40 and 50 years. It could be reasoned that at these ages most of the women have stopped child bearing and therefore have more time for agricultural production and other IGAs. Almost of the women are married (98\%). Though Yahaya (1995) who used women farmers in North Central Nigeria and Onuorah (1992) rural women in Anambra L.G.A., reported most of their respondents as being married; $87.7 \%$ and $82 \%$ respectively, none of themwas as high as was shown in this study. There is a difference of $10 \%$ between the number of married respondents in this study and the highest recorded $(88.0 \%)$ in the two studies mentioned. This must be a result of higher percentage of divorce and widowhood in those areas.

The family size is defined as the member of people eating from the same pot on regular basis. The respondents have between one and five children $(56.2 \%)$ and an average of four children each. Over half of the married ones $(52.6 \%)$ are the only wife of their husband and they have an average of three dependents. This gives a mean family size of nine. This is close to the findings of Norman (1972), Nwosu (1975) and Ladele (1990) who reported a family size of about eight people.

Education here refers to formal education. As many as $20.32 \%$ of the respondents have no formal education; $17 \%$ did not complete primary education while about $21 \%$ completed primary school. This depicts low educational level among the respondents. This agrees with earlier studies by Akinola (1983) and Ewuola (1985) who reported low educational level among farmers in Ondo State. Main occupation is defined as the occupation or IGA that respondents devote most of their time and energy to. It will be observed that the main occupation is crop farming (45.7\%) followed by trading (29.6\%). This collaborates WID (1994) finding that Nigerian women concentrate primarily on agricultural and petty trade. It is also observed that most of the respondents have been in the occupation for 16-20 years (27.09\%) and $18.90 \%$ between $10-15$ years considering the fact that many of the respondents fall between ages 40 to 60 years with an average age of 34 years, it means that most of them have consistently maintained their main occupation. 
Christianity is the dominant religion with $76 \%$ practicing, while $17 \%$ are traditional religionists and $7 \%$ Moslems. An earlier study of rural women in Anambra Local Government Area of Anambra State by Onorah (1992) reported 89\% Christians and 11\% traditional religionist. No Moslem was reported. The high percentage of Christians is typical of the South East of Nigeria with low percentage of traditional religionist. Recording 7\% Moslems in this study is atypical of Anambra State and is a very recent development. However it should not be very surprising given the commercial status of Anambra state that accommodates Hausa (Moslem) traders dealing in all kinds of wares including cattle and meat business.

From information from the FGD religion plays a vital role in the perception of the cause and remedy of erosion especially in gully erosion areas. In Osumenyi where a big gully has developed over the past four years, it was a subject of great controversy. The Christians had no explanation for the cause of the gully, but the traditional religionists believed that a god had been offended and was angry and must be appeased. The Christians saw this as fetish and refused to be part of the appeasement. The Christian declared five days fasting and prayer to ask for God's intervention. The traditional religionists' appeasement of the angry god could not be carried out since it required very expensive sacrifices which cost could not be borne by the few traditional religionists. No practical scientific step was taken to forestall further advancement of the gully. The people whose homes had been submerge or threatened had been given parcels of land to build new homes.

Education here refers to formal education. As many as $20.32 \%$ of the respondents have no formal education; $17 \%$ did not complete primary education while about $21 \%$ completed primary school. This depicts low educational level among the respondents. This agrees with earlier studies by Akinola (1983) and Ewuola (1985) who reported low educational level among farmers in Ondo State.

Table 5: Farm related activities of respondents

\begin{tabular}{|l|l|}
\hline Activities & Percentage \\
\hline Farm Ownership & \\
Yes & 95.0 \\
No & 5.0 \\
\hline Type of farm & \\
Communal & 2.1 \\
Personal & 93.4 \\
Communal and Personal & 4.5 \\
\hline Location of farm & \\
On slope & 7.6 \\
In the valley & 64,2 \\
On level ground & 29.2 \\
\hline Farm size (in hectares) & \\
$>1$ & 72.7 \\
$>2$ & 7.6 \\
$>3$ & 2.4 \\
$>4$ & 1.2 \\
$>5$ & 1.0 \\
$<5$ & 5.5 \\
\hline Duration of farming in years & \\
$\mathbf{1 - 5}$ & 7.2 \\
$\mathbf{6 - 1 0}$ & 11.7 \\
$\mathbf{1 1 - 1 5}$ & 13.6 \\
$\mathbf{1 6 - 2 0}$ & 25.3 \\
$\mathbf{2 1 = 2 5}$ & 16.9 \\
$\mathbf{2 6 - 3 0}$ & 8.9 \\
$\mathbf{3 1 - 3 5}$ & 4.6 \\
$\mathbf{3 6 - 4 0}$ & 3.0 \\
$\mathbf{4 1}$ and above & 4.8 \\
\hline
\end{tabular}

\section{Farm related activities of respondents.}

Table 5 shows the farm related activities of respondents. The study showed that $95 \%$ of the respondents have farms. The five percent of the women that do not own farms might be engaged fully in non-agro based IGAs. About $93 \%$ of these farms are personally owned. Most of the farms are located in the valley $(64.2 \%)$, implying that most of the farms will be adversely affected by erosion and flood water from the slopes. The farms in the valley run the risk of over flood since the water collect in the valley. The mean farm size stands at 5.6 hectare (ha). Yahaya (1995) in study however recorded farm size of less than 5 ha. by $58.5 \%$ respondents while $21.3 \%$ owned 6 to 10 ha. The large mean size recorded in this study does not however agree with picture painted about population density and pressure on land by Onwumerobi (1993) which portrays lack of adequate land space which results in male migration tendency. It was however discovered that a few claim of large hectares of ownership of land as large as 40ha resulted in this high mean. When these extremes were removed and the mean calculated, a mean of 2.7 ha resulted. It will be seen that most of the respondents $(72.7 \%)$ have less than 1ha. of farmland. This agrees with the report by Onwumerobi (1993) on the high population density 
and consequently pressure on land. Conclusively, the respondents are smallholder farmers. From the FGD in gully erosion areas some of the women have been completely dispossessed of farmland as a result of submergence into erosion gullies.

The average duration for which respondents have farmed is 11 years. About $25.3 \%$ have farmed for $16-20$ years while $16.9 \%$ have been farming for 21-25 years. With an average age of 34 years, it is likely that at the age of 22 years most must have gotten married and started owning their own farms. Before marriage they complement their mother's efforts. WID (1994) recorded that Nigerian women aged 15 years and above engage in agricultural production.

\section{Income Generating Activities}

From the result of the questionnaire survey which is reflected in Table 6 the study revealed that Anambra State rural women are engaged in multiple and diverse IGAs, the most notable IGAs are crop farming (87.9), cassava processing (88.2), keeping of local fowl (75.4\%), palm oil processing (62.1\%) and goat breeding (54.5\%). From the FGD it was discovered that women plant pepper, garden egg, cassava, yam, okro, sweet potato, corn, melon, cocoyam, oranges, pap-paw, sour sop, grape, pure apple mango, leafy green vegetables like green, fluted pumpkin, pumpkin, avocado pea, native pea. In Odekpe (Slight sheet erosion area) and Ebenebe (Mild gully erosion area) they grow rice. Dry season vegetable cultivation is popular in Odekpe. Furthermore, from information from FGD it was discovered that most of these agro-based IGAs are seasonal. During the farming season which is between February and August (Udo, 1970) the farming activities get 100\% attention. During harvesting and dry season, food processing is at its peak. Animal husbandry is practiced all year round with the most popular being keeping of local fowl (75.4\%) and goat keeping(54.5\%). This however flourishes more during the dry season when there is less casualty resulting from cold, flood and disease. Dry season vegetable production flourishes in mild sheet erosion area (Odekpe) since the place is by the River Niger and therefore there is ready water for irrigation.

Table 6: Women involvement in different Agro-based income generating activities

\begin{tabular}{|l|l|}
\hline Income generating activities & Involvement \\
\hline Crop farming & 87.75 \\
Palm oil processing & 61.75 \\
Cassava processing & 87.95 \\
Oil bean processing & 8.5 \\
Breadfruit processing & 19.9 \\
Keeping of local fowl & 75.4 \\
Keeping of improved breed & 38.1 \\
Goat & 54.85 \\
Sheep breading & 18.55 \\
Pig breeding & 3.6 \\
Dog breeding & 8.6 \\
Fishing & 3.1 \\
Sale of vegetables & 62.9 \\
Sale of grains & 29.6 \\
Sale of fuelwood & 2.65 \\
Basket weaving & 7.75 \\
\hline
\end{tabular}

The Obiofia (Nnewichi) women in the devastating gully erosion area have this to say:

"We do not have any other source of income except farming and keeping of a few fowls and goats. We used to get enough cassava to eat and sell. We used to do a lot of palm oil processing but we do not get much from it anymore since most of our palm trees have been washed away by the gully."

The result shows that rural women depend mainly on land to source their income. This confirms why women are alluded to as special victims of environmental degradation (Dankelman and Davidson, 1998; O'Connel 1994; Nyoni, 1986; and Banuri, T and Holmberg, J, 1992). This is because when the land is affected, their very existence is threatened. As expressed further by Sigot (1995), "poor rural women bear the burden of environmental degradation especially in rural areas. They often have special relationship with the natural environment by virtue of their direct and heavy dependence on such primary natural systems as land, water and forest for survival". This is typified by the statement made by these women which shows that the loss of land has eroded their source of income and family food security. 


\section{Income generating activities in sheet and gully erosion areas}

Table 7: Women involvement in income generating activities in sheet and gully erosion

\begin{tabular}{|l|l|l|}
\hline \multirow{2}{*}{ Income generating activities } & Level of involvement \\
\cline { 2 - 3 } & Sheet & Gully \\
\cline { 2 - 3 } & Percentage \% & Percentage \% \\
\hline Crop farming & 91.2 & 84.3 \\
\hline Cassava processing & 96.6 & 79.3 \\
\hline Palm oil processing & 74.4 & 49.1 \\
\hline Breadfruit processing & 24.9 & 14.9 \\
\hline Oil bean processing & 9.8 & 7.1 \\
\hline Keeping of local fowl & 77.1 & 73.7 \\
\hline Keeping of improved breed & 39.1 & 37.0 \\
\hline Goat keeping & 42.1 & 67.6 \\
\hline Sheep keeping & 16.8 & 20.3 \\
\hline Sales of vegetable & 70.3 & 55.5 \\
\hline Sale of grains & 30.5 & 28.5 \\
\hline Sale of Fuel wood & 1.7 & 3.6 \\
\hline
\end{tabular}

Table 7 shows the degree of involvement in the different IGAs in sheet and gully erosion areas. It provides a base for comparism on which to draw conclusion about the income generating activities of rural women in sheet and gully erosion areas. The main income generating activities will be used as basis for comparism.

From the study, in most cases more women from sheet erosion areas are more involved than women in gully erosion areas. It is expected that since there are more damages on land in gully erosion areas, less people are likely to be involved in those IGAs that are sourced from land. It is expected that women in sheet erosion areas will have the confidence to embark on land sourced IGAs because of less environmental threat and the expectation of bounty harvest. The rural women in gully erosion areas will have misgiving because of the level of risk as a result of the fear of losing their crops and livestock in erosion gullies. It will be noticed however that goat and sheep keeping flourishes more in gully erosion areas. This is because goats and sheep are normally tethered, so the risks of their falling to their death in erosion gullies are unlikely unless they break loose.

\section{Effect of erosion on income generating activities of rural women}

To establish the effect of erosion on IGAs in rural women in Anambra state, the two erosion types will be discussed, separately. This is to appreciate the difference (if any) of the effect of the two erosion types (sheet and gully) on the different income generating activities. The main income generating activities are discussed.

Table 8: The effect of erosion on the income generation activities of rural women in sheet and gully erosion areas

\begin{tabular}{|l|l|l|}
\hline Income generating activities & Negatively affected by sheet (\%) & Negatively affected by gully (\%) \\
\hline Crop farming & 44.6 & 59.9 \\
\hline Food processing & 48.1 & 25.6 \\
\hline Keeping of local fowl & 50.7 & 50.3 \\
\hline Keeping of improved breed & 28.5 & 25.3 \\
\hline Goat rearing & 62.3 & 33.7 \\
\hline Basket making & 2.4 & 20.9 \\
\hline \multicolumn{2}{|l}{} \\
\hline
\end{tabular}

From Table 8 it is observed that erosion affects all the income generating activities in both sheet and gully erosion areas in varying degrees. The most negatively affected by sheet erosion are rearing of goat (62.3\%), keeping of local fowl $(50.7 \%)$, food processing $(48.1 \%)$ and crop farming $(44.6 \%)$. The most negatively affected in gully erosion are crop farming (59\%), keeping of local birds (50.30\%) goat rearing (33.7\%) and food processing $(25.6 \%)$. In spite of the fact that the study shows that more respondents in sheet erosion areas are more into crop farming than in gully erosion areas, more of the respondents in the gully erosion indicated that crop farming is adversely affected by erosion. This confirms that land is more affected in gully erosion areas. This agrees with the information given by Igbozurike (1981) and NEST (1991) about loss of farm lands and submergence of crops into erosion gullies. The following information from the FGD supports these allusions;

"Our main problem is over flooding of the Niger River. The flood destroys our crops. This happens every four years. When it happens, we do not have food to eat or seeding for the next planting season. But when there is no flood we have good harvest".

Odekpe Women Farmers (in Slight sheet erosion area)

"The flood does not destroy our crops. It is only those living in the valley that their crops are affected. It is as a result of the road that was constructed". 


\section{Ojoto uno Women farmers (in Moderate sheet erosion area)}

"Our farmlands, crops and homes have been swallowed up in the gully. Some of us do not have a place to farm at all. We have tried everything including fasting and prayer to stop the advance of the gully. The African traditional religionists say that the gods are angry and we should make sacrifice. We the Christians have refused. We are desperate because we know that when the rains come again more crops, land and houses will be lost".

Osumenyi Women farmers (in Severe gully erosion area)

"We do not have any source of income except farming and keeping of few fowls and goats. We used to do a lot of oil palm processing but we do not get much from it now since most of our palm trees have been swallowed by the gully". "We have a vast farmland called "Agu" where we farm. Part of it has been swallowed up by the gully. We can not get to the remaining land because the gully is so deep that we cannot pass. We do not have enough food to eat. Our children have stopped going to school because we do not have enough money. We depend on the money that our husbands get from their Okada (motorcycle) transport which is not enough. Some of our husbands have gone to the cities in search of what to do".

Nnewichi Women farmers (in Devastating gully erosion area)

In Table 8 the difference in the response ratio of the people who indicated that food processing activities are adversely affected by erosion in sheet and gully erosion areas is worthy of note $(48.1 \%$ and $25.6 \%$ respectively). This must be because more people are involved in food processing in sheet erosion areas than in gully erosion areas.

\# The indication of the adverse effect of erosion on keeping of local birds in sheet and gully erosion areas is the same (about 50\%) in both cases. It will be thought that since some of the birds fall into the erosion gullies that there should be more casualty in gully erosion areas. From the FGD however it was discovered that people in slight sheet erosion areas do not keep fowls because of the flood they experience which they claim drown the birds. This explains the equal effect. The large difference in the response rate in keeping of goat in the sheet and gully areas $(63.3 \%$ and $33.7 \%$ respectively) mirrors the effect of flood and the drowning of livestock in flood water in sheet erosion areas. Considering the traditional method of goat keeping which is tethering goats in a shed inside the compound which is normally fenced and providing fodder for them it ought to be safe to keep. That means the risk factor will be low.

\section{Conclusion and recommendation}

The study showed that Anambra State rural women are engaged in multiple and diverse income generating activities that are agro-based; thus, land is a very important resource in determining family food security in the study area. Erosion which is the most prominent type of land degradation in Anambra State is affecting their income generating activities of the women in varying degrees depending on the type of IGA and the erosion type. This is a big threat to their family food security.

With the above findings in this study, it is recommended that communities in Anambra State should be thought different methods of erosion control and should be encouraged to have other non agro income sources in case of crop failure.

\section{References}

[1]. Akinola, C.A.(1983) "An Analysis of Some Selected Factors Related to the Adoption of Selected Crop Production Recommendations by Farmers in Funtua ADP" Unpublished Ph.D Thesis, University of Ibadan.

[2]. Banuri, T. and Holmberg, J. (1992) Governance for Sustainable Development: A Southern Perspective. International Institute for Environment and Development, London.

[3]. Dankelman, T. and Davidson,J. (1998) Women and Environment in the Third World: Alliance For the Future. Earthscan Publications Limited, London.

[4]. Eboh, E. and Obiechina, C.O.B. (1993) "Farm Level Technologies for Coping with Shortening fallows . Their Application and Impact in Smallholder Agriculture: A Case Study of Enugu State" Productivity. A Quarterly Journal. 34(4)

[5]. Eboh, E. (1995) Poverty, Population Growth and Environmental Degradation.: A Vicious Circle Of Human Misery" Rural Development in Nigeria. Concepts,Processes and Prospects Auto-Century Publishing Co., Ibadan.

[6]. Ewuola, S.O. (1985) “ An Analysis of the Effectiveness of Smallholder Farmer Credit Programme in Ondo State" Unpublished Ph.D Thesis, University of Ibadan.

[7]. Igbozurike, U.M. (1981) Soil Erosion Prevention and Control Manual. Fried Ebert Foundation Lagos and Nigeria Environmental Study /Action Team, Ibadan.

[8]. Ladele, A.A. (1990) "Socio-Economic Analysis of the Impact of Agricultural Cooperatives Kwara and Oyo States" An Unpublished Ph.D Thesis, University of Ibadan, Ibadan, Oyo State.

Organizations on Farmers in

[9]. Nigeria Environmental Study/ Action Team, (1991) Nigeria Threatened Environment: A National Profile, NEST, Ibadan

[10]. Nyoni, S. (1986) “Africa Food Crisis: Price of Ignoring Village Women?"Nurturing the Fields Women and Environment,.

[11]. 'Connel, H. (1994) Women and the family. Women and World Development Series, Zed Books Limited, London. 
[12]. Ofomata, G.E.K. (1991) Soil Erosion Characteristics in the Forest Zone of South Eastern Nigeria. Ecological Disaster in Nigeria: Soil Erosion. Federal Ministry of Science and Technology, Lagos.

[13]. Sagua, N.O. (1988) Ecological Disaster in Nigeria: Soil Erosion. Federal Ministry of Science and Technology, Lagos.

[14]. Sigot, A.J. (1995) “ Discuss on Gender and Natural Resources Management” Towaards Common Ground: Gender and Natural Resource Management in Africa,Kenya

[15]. Udo, R.k. (1970) "The Scraplands of South Eastern Nigeria" Geographical Regions of Nigeria University of California Press, Berkeley.

[16]. Women in Development, (1994) The Status of Women in Nigeria. Cross River Branch 